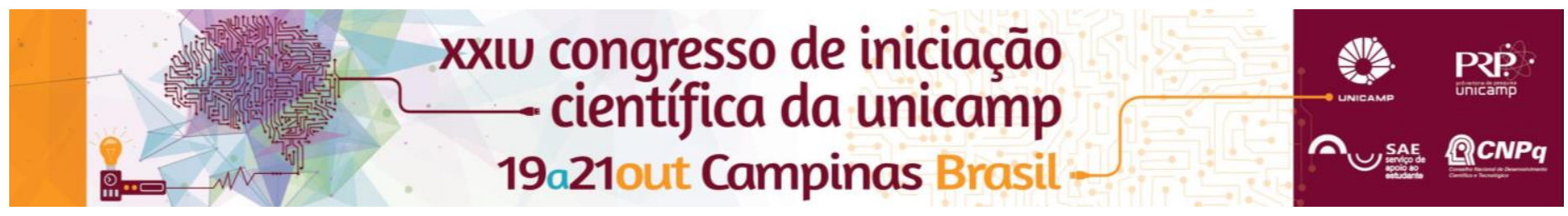

\title{
Desigualdades e variações de gênero nos anos iniciais da carreira acadêmica na Unicamp.
}

\author{
Mariana Ferraz Almiron*, Ana Maria Fonseca de Almeida.
}

\begin{abstract}
Resumo
Com o alongamento da escolarização das mulheres e seu maior acesso aos diplomas de doutorado em diversos países, importa perguntar também sobre seu acesso e desenvolvimento na carreira acadêmica e de pesquisa em universidades. O presente projeto pretendeu examinar a situação particular das docentes mulheres no meio acadêmico e investigar os desafios enfrentados por jovens professores recém-contratados numa universidade de pesquisa. Para isso, analisou as trajetórias familiares e profissionais de professores recém-contratados na Unicamp por meio do estudo de seus currículos depositados na Plataforma Lattes e de entrevistas com um subgrupo selecionado entre estes docentes.
\end{abstract}

\section{Palavras-chave:}

Carreira acadêmica, gênero, desigualdade.

\section{Introdução}

Desde os anos 2000, o alongamento da escolarização das mulheres tem sido relatado em diversos países ${ }^{1}$. Uma parte desse fenômeno implica num maior acesso das mulheres a diplomas de doutorado. A feminização de uma carreira, porém, não indica necessariamente que, em seu interior, a situação seja igualitária entre homens e mulheres. Segundo algumas autoras, as mulheres têm acesso à carreira, mas encontram obstáculos em sua progressão e na construção de trajetórias de excelência. Algumas hipóteses são comumente formuladas para explicar como isso ocorre. Elas podem ser divididas em dois grandes grupos: por um lado, há autores e autoras que apontam como principal causa das desigualdades os critérios definidos para progressão nas carreiras e a estrutura em si que as organiza. Por outro, há pesquisas que apontam para a incompatibilidade entre exigências da vida doméstica e da vida profissional das mulheres acadêmicas como fonte originária dessa situação. O contexto brasileiro pode trazer novas perspectivas na compreensão da produção e da reprodução de desigualdades de gênero na carreira acadêmica. $O$ principal objetivo da pesquisa resumiu-se à investigação da trajetória pessoal e profissional/acadêmica de um grupo selecionado de docentes da Unicamp em início de carreira, para, dessa forma, mapear os conflitos e obstáculos encontrados por docentes homens e mulheres desse grupo. Por fim, procurou-se compreender de que maneira o gênero conforma a experiência vivida por eles e elas no espaço profissional.

\section{Resultados e Discussão}

Cada instituição pública de pesquisa possui suas exigências para a promoção na carreira. No caso da Unicamp, as exigências são diferenciadas de acordo com os institutos/faculdades, através de um Perfil Docente, e são as mesmas para docentes homens e mulheres. Essa igualdade de pré-requisitos para promoção na carreira somente leva em conta o contexto profissional de cada docente, desconsiderando qualquer tipo de contexto familiar e social. Portanto, até que ponto podemos questionar critérios de seleção ou promoção acadêmica que desconsideram o contexto desigual no qual os candidatos e candidatas se formaram socialmente? O caso da Unicamp nos faz concluir que a carreira dentro de seu quadro é um processo percorrido por exigências DOI: 10.19146/pibic-2016-51787 que, olhando superficialmente, não nos levam a pensar que existam desigualdades de gênero em seu interior, visto que sua ascensão é tida como meritocrática, onde os pré-requisitos são os mesmos para homens e mulheres. Uma questão a se pensar é como o tempo é administrado entre homens e mulheres para que haja uma conciliação entre a construção da carreira acadêmica e o cotidiano da vida doméstica. Os critérios estabelecidos para promoção pensados isoladamente não remetem, de início, à ideia de que as desigualdades de gênero estão presentes na carreira acadêmica. Porém, ao analisa-los casados a outros fatores sociais, como a maternidade, paternidade, divisão de tarefas domésticas, impressões sobre sujeitos e seus papeis socialmente construídos, tais critérios para promoção podem contribuir para gerar e manter desigualdades de gênero na ascensão da carreira acadêmica na Unicamp.

\section{Conclusões}

A bibliografia lida apontou, de forma geral, que a carreira acadêmica no Brasil expandiu-se nos últimos 30 anos e que tal expansão acarretou em um aumento da parcela de doutores que adentraram a profissão acadêmica. Nas entrevistas realizadas, parte dos docentes, tanto homens como mulheres, entende que a desigualdade de gênero não atua diretamente na trajetória e ascensão da carreira acadêmica. Em contraposição a isso, algumas falas apontam que a desigualdade se revela quando o âmbito profissional não é isolado do contexto social. Seria importante analisar o quanto a percepção, por parte dos docentes, de que o desenvolvimento da carreira está ancorado apenas a critérios meritocráticos, escamoteia a forma como as desigualdades de gênero são empregadas tanto nos processos seletivos, quanto na ascensão competitiva da carreira. Compreendemos que para um aprofundamento das questões levantadas nessa pesquisa importa observar que a percepção das docentes sobre si mesmas e de seus colegas sobre elas - ao negarem a desigualdade de gênero - é socialmente influenciada por um contexto já marcado pela depreciação ideológica sobre a figura da mulher.

\footnotetext{
${ }^{1}$ Baudelot e Establet, 1992; Mason e Ekman, 2007, Rosenberg, 2001; Beltrão
} e Alves, 2004 